\title{
A Multi-Dimensional Assessment Model to Evaluate Web Based Learning Systems
}

\author{
Anal ACHARYA ${ }^{1}$, Devadatta SINHA ${ }^{2}$ \\ ${ }^{1}$ St. Xavier's College, Kolkata, India \\ ${ }^{2}$ University of Calcutta, Kolkata, India \\ anal_acharya@yahoo.com,devadatta.sinha@gmail.com
}

The growth of communication technology in the last decade has prompted researchers to develop web based learning systems for various types of applications. The entities involved in the development of such systems are learners, instructors, system designers, administrators to name a few. With varying nature of applications and entities involved, the task of evaluating these web based learning systems appears quite challenging. The present study uses factor analysis to develop an assessment model for evaluating the web based learning systems developed by the authors. The analysis is performed on a data set derived by applying a survey instrument on a set of 140 learners using these systems. These learners ranked 20 items used for evaluation in order of their perceived degree of importance. It was found that the most important dimension was learning outcome which coincides with the general outcome of any mode of learning.

Keywords: Web Based Learning Systems, Web based Learning Assessment, Survey Instrument, Factor Analysis, SPSS

$\mathbf{1}^{1}$ Introduction

In recent times the most important innovation that has changed the face of educational technology is web-based education. This has been possible due to tremendous advancement in the field of computer networks and communication technology. There are two ways in which web based learning may be implemented. The primitive form of this type of learning is Electronic Learning (E-Learning). ELearning is a general term that is used for learning from any electronic device such as radio, television, computer and all other devices that may be invented in the near future that are electronic in nature [8]. A major disadvantage of this form of learning is lack of ubiquity and idle time utilization. The advancement in the field of mobile communications in late 90's gave birth to Mobile Learning (M-Learning). Mobility added to E-Learning is M-Learning. Mlearning enables learning independently of place and time as is ubiquitous through the use of wireless networks and mobile devices [21]. The effectiveness of web based learning is enhanced when several learners attempt to learn something together. In this form of learning, learners can capitalize on one another's resources and skills. Thus Collaborative learning (C-Learning) [7],[12] techniques may be used in E-Learning and M-Learning environments to increase their efficacy.

Web learning systems are multidisciplinary in nature. They are used by learners from various domains who have varied experiences of using these systems. The design goals of these systems are thus highly dependent on the nature of the application and the knowledge of the learner. Efficient design of web learning systems is also dependent on the quality of the instructors, administrators and system designers. Thus there are several factors upon which the success of a web learning system depends. The aim of this study is to develop a multidimension model to evaluate web learning systems. It is to be noted that this assessment model is not general in nature. It has been derived on the basis of a survey performed to assess the web learning systems developed by author [2],[3],[4].

Various methods have been employed by the researchers for assessing web based learning systems. A method typically used by several 
researchers is to develop a set of quality metrics for this purpose. Gafani [13] has used the ISO/IEC 9126 model to propose a set of quality metrics for evaluating Mobile Learning Systems. These metrics were defined and empirically validated for mobile wireless systems. Parsons et al. [24] proposed an assessment of mobile learning quality in terms of learner experience. A conceptual frame work for a mobile learning application was constructed and quality metrics were developed for this purpose. Wang [26] developed a comprehensive model and instrument for measuring learner satisfaction with asynchronous e-learning systems. This study performed different reliability and validity tests for analyzing data from a sample of 116 respondents of a survey. The norms of the evaluation instrument were developed from these. In a slightly different vein, Hwang et al. [17] developed a computer assisted website evaluation system for evaluating educational websites. Soft computing techniques like fuzzy theory, grey systems and group decision methods like Analytic Hierarchy Process (AHP) have been used for this purpose. It has been found that the developed system is capable of selecting proper criteria for evaluating websites. Alkhalaf et al. [5] has performed a survey on students of two different universities of Saudi Arabia to find the impact of e-learning systems on the learners. Statistical analysis employed on this survey data found that e-learning systems show positive impact on student learning.

In light of the above discussion the organization of this paper is as follows: The following section gives a brief description of the web learning systems developed by the authors and the items used to evaluate these systems. These items are ranked by the users of these systems using a survey. The methodology used for conducting the survey and selection of participants are then described in the next section. Factor analysis is next performed on this survey data set to derive the dimensions of the assessment model with associated item sets along with relative importance of each factor. Trends noticed in the assessment model are then discussed. The study concludes with a parametric comparison of the current study with certain pioneering research works done in this field.

\section{Origin of the Assessment Model}

This section is described into two subsections. The first subsection describes the background behind development of the assessment model whereas the second subsection proposes the set of items that are used in the assessment model.

\subsection{Web Learning Systems used for Assessment}

This section describes the web learning systems developed by the authors that have been used in developing the assessment model. Concept Maps (CM) [22] have been used as a mind tool for structuring and organizing knowledge in these systems. A concept map is a directed graph that shows the relationship between the concepts. The directed arcs indicate the sequence a learner should follow to learn a subject. Fig 1 shows an example of a concept map of learning corresponding to a subject that has eight concepts $\mathrm{C} 1, \mathrm{C} 2, \mathrm{C} 3, \ldots ., \mathrm{C} 8$ shown the form of the vertices of a graph. The directed edges of the graph indicate the sequence in which lessons are to be delivered to the learner. Thus in Figure 1 a student should first learn the concept $\mathrm{C} 1$ first followed by the concept $\mathrm{C} 2$. The concepts $\mathrm{C} 3$ and $\mathrm{C} 5$ can then be learnt simultaneously. Associated with the edge $\mathrm{C} 1 \rightarrow \mathrm{C} 2$ there is a confidence level of 0.12 which states that if the student fails to understand $\mathrm{C} 1$, then the probability for him failing to understand $\mathrm{C} 2$ is 0.12 [16]. A brief description of the web learning systems developed by the authors using concept maps is next discussed. 


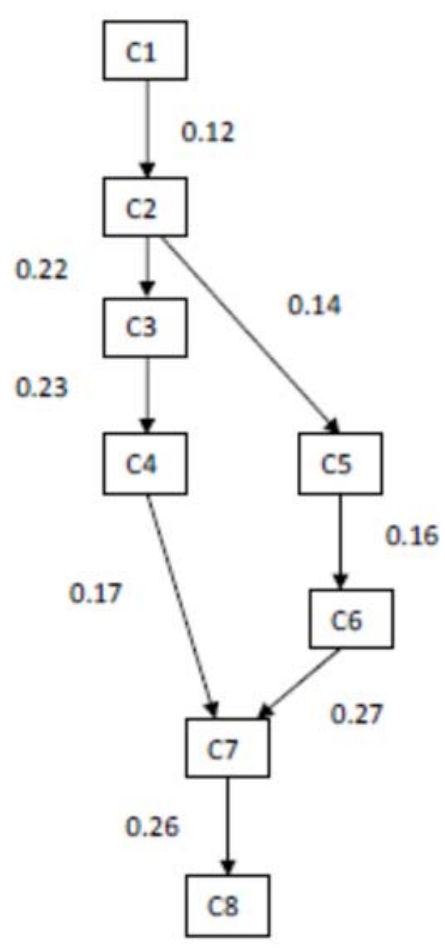

Fig. 1. A Concept Map of learning

The authors [3] proposed an e-learning system where concept maps were generated in a automated fashion for remedial purpose. Direct Hashing and Pruning (DHP) Algorithm [28] was applied on student historical test records to generate a set of association rules and relative weights between the concepts. The process worked by first generating the 1-itemsets and then 2itemsets between the test items and then deriving the association rules between the concepts using these and Test Item Relationship Table (TIRT) (Hwang,2003) as input. Once the concept map of learning is constructed the Remedial Learning Path (RLP) can be computed from it. The proposed method was tested with a set of students enrolled in an introductory 'Java' course in some under graduate colleges in Kolkata, India and found to diagnose their learning problems satisfactorily. This system is acronymed as CM-DHP for farther reference.

A major drawback of this method is that relative weights of the concepts are not taken into account while computing the Remedial Learning Path (RLP). Thus the authors [4] proposed an extension of Concept Map which were called Weighted Concept Map (WCM). In this study relative weights were assigned to the concepts based on their degree of importance. Corresponding to a concept which is not properly learnt by a student, several RLPs were generated. The path for which the sum of products of weights and corresponding probability is maximum gives the best RLP. This RLP is to be used for remedial learning. This approach was tested with a set of middle school students and was found to diagnose their learning problems satisfactorily. This system is acronymed as WCM-DHP for farther reference.

The concept map generated by CM-DHP is used as a sequence to develop an architecture of a learning system in mobile environment [2]. In this work an Intelligent Diagnostic and Remedial Learning System (IDRLS) was proposed which helps the learner identify the concepts he is deficient in and what are the related concepts he should revise. The architecture uses an inference engine to generate association rules. The architecture also uses a learning portfolio to generate learning guidance which is sent as a form of SMS to the learner. A prototype of the system was implemented using Android Emulator [25]. t-test was used to compare the pretest and posttest marks of a set of learners for an elementary 'Java' course and results found satisfactory.

Finally collaboration techniques were applied on a set of college students for studying an elementary course in Java. The students were divided into three groups. The first group was given to study the subject in the theory class and the second group was given to study the subject in the practical class. These two groups collaborate between themselves using mobile devices to finalize the concept map of learning. The finalized concept map is sent to the third group in the form of short messages. The task of the third group was to prepare the learning and evaluation system. A prototype of such learning system for the group was then developed using Android Emulator. t-test between the marks secured 
by students before and after collaboration indicates that this form of learning has been effective. The development of this Collaborative Learning System (CLS) is currently under progress.

\subsection{Item Set in Assessment Model}

Based on these systems a set of 20 items are proposed to develop a model for assessing web based learning systems. The items along with their purpose are now discussed. In any learning system the most important entity is the learner. Thus in web based learning systems learner's computer aptitude $\left(\mathrm{I}_{5}\right)$ is the foremost requirement. Learner will also require good communication skills ( $\left.\mathrm{I}_{14}\right)$ to communicate with his course instructor. In this respect instructors' friendliness ( $\mathrm{I}_{20}$ ) may be an added boost for the learner. In web based learning systems learners should be able to assess the learning system at any time from any location. Thus the instructor should be available $\left(\mathrm{I}_{11}\right)$ to the learners most of the times. Communication skills are also required when several learners collaborate (I19) with each other to perform a certain task. After learners complete the learning process they are to be evaluated ( $\left.I_{2}\right)$. Another mode of evaluation in this regard is to understand group dynamics in regard to collaboration process. This aspect is surveyed in System Evaluation ( $\left.\mathrm{I}_{17}\right)$. Learners should be able to evaluate themselves ubiquitously i.e. they appear for a test and the results are immediately messaged to them $\left(\mathrm{I}_{6}\right)$ irrespective of their location. Yet another way of evaluating the quality of learning is to check learner satisfaction ( $\left.\mathrm{I}_{12}\right)$. This is often done using a survey. A learning system should have a sequence in which lessons are to be delivered to the learners. Some form of knowledge management tools $\left(\mathrm{I}_{3}\right)$ is often used for this purpose. Lessons are stored in the form of learning objects. Designing good quality learning materials require instructor knowledge $\left(\mathrm{I}_{1}\right)$. A lot of effort is saved if the Learning Objects (LO) are reusable ( $\mathrm{I}_{9}$ ). In certain applications learners are first given to learn the subject in traditional manner. Based upon their performance in the subsequent examinations, some form of remediation ( $\left.\mathrm{I}_{15}\right)$ may be offered to weaker students. A learning application is often evaluated on the quality of the system. A computer system should not be assessed by all users i.e. it should be secure (I4). It should also be easy to use $\left(\mathrm{I}_{7}\right)$ by all users. It should support increase in the number $\left(\mathrm{I}_{16}\right)$ of learners. However this increase should not slow down $\left(\mathrm{I}_{8}\right)$ the system. It should also yield results which the learner can depend $\left(\mathrm{I}_{10}\right)$ on. The system may require some form of maintenance $\left(\mathrm{I}_{18}\right)$ by the system administrators from time to time. Finally, the ultimate objective of any form of learning is satisfactory employment ( $\left.\mathrm{I}_{13}\right)$. The entire set of items and their reference code are given in Table 1.

Table 1. List of items used for assessing Web based Learning Systems

\begin{tabular}{|l|l|}
\hline $\begin{array}{l}\text { Item } \\
\text { Reference }\end{array}$ & Item Name \\
\hline $\mathrm{I}_{1}$ & $\begin{array}{l}\text { Instructor } \\
\text { Knowledge }\end{array}$ \\
\hline $\mathrm{I}_{2}$ & Learner Evaluation \\
\hline $\mathrm{I}_{3}$ & $\begin{array}{l}\text { Knowledge } \\
\text { Management }\end{array}$ \\
\hline $\mathrm{I}_{4}$ & Security \\
\hline $\mathrm{I}_{5}$ & $\begin{array}{l}\text { Learner's } \\
\text { Aptitude }\end{array}$ \\
\hline $\mathrm{I}_{6}$ & Interactivity \\
\hline $\mathrm{I}_{7}$ & Ease of use \\
\hline $\mathrm{I}_{8}$ & Timeliness \\
\hline $\mathrm{I}_{9}$ & $\begin{array}{l}\text { Learning } \\
\text { reusability }\end{array}$ \\
\hline $\mathrm{I}_{10}$ & Rejiabt(LO) \\
\hline $\mathrm{I}_{11}$ & Instructor's availability \\
\hline $\mathrm{I}_{12}$ & Learner satisfaction \\
\hline $\mathrm{I}_{13}$ & Employment \\
\hline $\mathrm{I}_{14}$ & $\begin{array}{l}\text { Learner's } \\
\text { communication skills }\end{array}$ \\
\hline $\mathrm{I}_{15}$ & $\begin{array}{l}\text { Remedial } \\
\text { support }\end{array}$ \\
\hline $\mathrm{I}_{16}$ & Scalability \\
\hline $\mathrm{I}_{17}$ & System Evaluation \\
\hline $\mathrm{I}_{18}$ & Maintainability \\
\hline $\mathrm{I}_{19}$ & Collaborative Support \\
\hline $\mathrm{I}_{20}$ & Instructor friendliness \\
\hline
\end{tabular}


It is to again be stressed that these suggested items used for developing the assessment model is not general in nature. It has been proposed based on the learning systems developed by the authors.

\section{Survey}

The users of the systems defined in the previous section were considered for survey. All the systems users except WCM-DHP were college level students. The users of WCM-DHP were middle school students. They were not considered as it was thought that their maturity was not high enough to be considered for the survey. The concept map constructed in CM-DHP used 60 undergraduate students studying an introductory course in Java in certain colleges in Kolkata. Based on the Concept Map obtained from this data set IDRLS was constructed. The experiments conducted in CLS consisted of under graduate students from three colleges in Kolkata. These colleges are acronymed as College A, College $\mathrm{B}$ and College $\mathrm{C}$ respectively. 24 students were chosen from college A, 38 students from College B and 32 students from College C. However the 24 students of college A were a subset of the 60 students in CM-DHP and IDRLS. Thus the total number of students who have used at least one of the web learning systems is $60+38+32=140$. This is thus the sample count for the proposed survey. The details of the Web Learning systems along with their users and survey participants are summarized in Table 2.

Table 2. Summary of System and Survey participants

\begin{tabular}{|l|l|l|l|}
\hline $\begin{array}{l}\text { System } \\
\text { Reference }\end{array}$ & System Objective & Learners involved in experimentation & $\begin{array}{l}\text { Survey } \\
\text { Participants }\end{array}$ \\
\hline CM-DHP & $\begin{array}{l}\text { Construction of CM of } \\
\text { learning }\end{array}$ & $\begin{array}{l}\text { 60 students studying a course 'Introductory } \\
\text { Java' in under graduate level }\end{array}$ & All \\
\hline IDRLS & $\begin{array}{l}\text { Implementation of learning } \\
\text { system based on CM-DHP } \\
\text { in Mobile environment }\end{array}$ & Same as above & All \\
\hline $\begin{array}{l}\text { WCM- } \\
\text { DHP }\end{array}$ & $\begin{array}{l}\text { Construction of weighted } \\
\text { CM of learning }\end{array}$ & $\begin{array}{l}48 \text { students of class VII for the physics } \\
\text { course 'Force and Motion' None }\end{array}$ & $\begin{array}{l}24,38,32 \text { students from three colleges } \\
\text { studying 'Introductory Java' course } \\
\text { collaboratively }\end{array}$ \\
\hline CLS & $\begin{array}{l}\text { Construction of CM of } \\
\text { learning using collaboration }\end{array}$ \\
\hline
\end{tabular}

A survey sheet was distributed to all the 140 students for obtaining their feedback. The survey sheet was divided into three parts. Part I queries about the background of the student, Part II asks the learners to rank the 20 items of Table 1 based on the degree of importance whereas Part III asks the students to describe their learning experiences using either of the Web based learning systems described in Table 2. Out of the 140 students 113 responded by submitting the survey sheet. Of them 97 survey sheet did not contain any missing fields. To ensure uniformity these survey data were considered for analysis purpose. A sample survey instrument form is attached in Appendix A.

\section{Statistical Analysis}

The data set obtained from a sample count of 97 students was analyzed for developing the assessment model. This process consists of four steps. Firstly factor analysis was performed on the data set to represent the data in suitable dimensions. In the second step the reliability of this form of factorization is checked using Cronbach Alpha. t-test is then applied between the derived factors to find the degree of significance between the factors. Finally, regression analysis was used to find the degree of importance of each items and factors. Part II of the survey data was used for analysis purposes. The entire simulations were carried out using Statistical Package for Social Sciences (SPSS) [6]. 


\subsection{Generating Factor Structure}

In this study Varimax rotation was used to find the factor structure. This method generates a small number of factors with large loadings and a large number of factors with small loadings.

Table 3. Factor Analysis of survey results

\begin{tabular}{|c|c|c|c|}
\hline $\begin{array}{l}\text { Factor } \\
\text { Reference }\end{array}$ & Items & $\begin{array}{l}\text { Factor } \\
\text { Loadings }\end{array}$ & $\begin{array}{l}\text { \% of Variance } \\
\text { Explained }\end{array}$ \\
\hline \multirow[t]{5}{*}{ Factor F1 } & $\mathrm{I}_{3}$ & 0.374 & \multirow[t]{5}{*}{$17.89 \%$} \\
\hline & $\mathrm{I}_{6}$ & 0.357 & \\
\hline & $\mathrm{I}_{9}$ & 0.537 & \\
\hline & $\mathrm{I}_{15}$ & 0.530 & \\
\hline & $\mathrm{I}_{19}$ & 0.496 & \\
\hline \multirow[t]{6}{*}{ Factor F2 } & $\mathrm{I}_{4}$ & 0.629 & \multirow[t]{6}{*}{$15.87 \%$} \\
\hline & $\mathrm{I}_{7}$ & 0.481 & \\
\hline & $\mathrm{I}_{8}$ & 0.240 & \\
\hline & $\mathrm{I}_{10}$ & 0.557 & \\
\hline & $\mathrm{I}_{16}$ & 0.539 & \\
\hline & $\mathrm{I}_{18}$ & 0.756 & \\
\hline \multirow[t]{5}{*}{ Factor F3 } & $\mathrm{I}_{1}$ & 0.826 & \multirow[t]{5}{*}{$13.10 \%$} \\
\hline & $\mathrm{I}_{5}$ & 0.482 & \\
\hline & $\mathrm{I}_{11}$ & 0.280 & \\
\hline & $\mathrm{I}_{14}$ & 0.692 & \\
\hline & $\mathrm{I}_{20}$ & 0.496 & \\
\hline \multirow[t]{4}{*}{ Factor F4 } & $\mathrm{I}_{2}$ & 0.551 & \multirow[t]{4}{*}{$12.13 \%$} \\
\hline & $\mathrm{I}_{12}$ & 0.112 & \\
\hline & $\mathrm{I}_{3}$ & 0.455 & \\
\hline & $\mathrm{I}_{17}$ & 0.673 & \\
\hline
\end{tabular}

This method also simplifies factor interpretation since each variable tends to be associated with one factor and each factor tends to be associated with small number of variables [1]. Table 3 shows the values of factor loadings for each of the 20 items specified in Table 1. Costello and Osborne (2005) suggested that factor loadings greater than 0.3 may be considered significant. Thus the factors $\mathrm{I}_{8}, \mathrm{I}_{11}$ and $\mathrm{I}_{12}$ are deleted as they do not satisfy this criterion. Mela and Kopalle [20] has found that multi collinearity can reduce parameter variance estimates. One way of checking multi collinearity is to compute the determinant of the correlation matrix (0.0032) which is greater than 0.0001 . Thus all the items used for developing the proposed assessment model are well correlated.

Another way to assess whether multi collinearity affects the survey data is to compute Kaser-Meyer-Oklin (KMO) statistic. Minimum value for this statistic should be 0.5 , values between 0.5 and 0.7 are mediocre, values between 0.8 and 0.9 are great whereas values greater than 0.9 are superb [15]. Bartlett's test for sphericity says that if the value is less 0.5 , then the results may not be considered significant. For the survey data set this value is 0.734 . Thus it may be concluded that survey data factors quite well. Also total variance explained by the four factors is $58.99 \%$. This value again indicates that the factors generated by factor analysis are consistent with the survey data. MacCallum et al. [19] have shown that if communalities are high, recovery of population factors in sample data is normally very good, regardless of sample size. Thus the sample size of 97 would be sufficient for present study. 
Table 4. Rotated Component Matrix

\begin{tabular}{|c|c|c|c|c|}
\hline \multirow{2}{*}{$\begin{array}{c}\text { Item } \\
\text { Reference }\end{array}$} & \multicolumn{4}{|c|}{ Factors } \\
\hline $\mathrm{I}_{1}$ & & & 0.503 & \\
\hline $\mathrm{I}_{2}$ & & & & 0.708 \\
\hline $\mathrm{I}_{3}$ & 0.575 & & & \\
\hline $\mathrm{I}_{4}$ & & 0.723 & & \\
\hline $\mathrm{I}_{5}$ & & & 0.466 & \\
\hline $\mathrm{I}_{6}$ & 0.175 & & & \\
\hline $\mathrm{I}_{7}$ & & 0.392 & & \\
\hline $\mathrm{I}_{9}$ & 0.553 & & & \\
\hline $\mathrm{I}_{10}$ & & 0.428 & & \\
\hline $\mathrm{I}_{13}$ & & & & 0.484 \\
\hline $\mathrm{I}_{14}$ & & & 0.484 & \\
\hline $\mathrm{I}_{15}$ & 0.463 & & & \\
\hline $\mathrm{I}_{16}$ & & 0.627 & & \\
\hline $\mathrm{I}_{17}$ & & & & 0.323 \\
\hline $\mathrm{I}_{18}$ & & 0.809 & & \\
\hline $\mathrm{I}_{19}$ & 0.542 & & & \\
\hline $\mathrm{I}_{20}$ & & & 0.543 & \\
\hline
\end{tabular}

Four factors (Table 3) were chosen with the cut-off value for eigen values being 2.0. This value conforms to the point of inflexion as seen in the scree plot (Fig 2). Table 4 shows the result of rotated component matrix with items $\mathrm{I}_{8}, \mathrm{I}_{11}$ and $\mathrm{I}_{12}$ left out. The item $\mathrm{I}_{6}$ is next deleted from rotated component matrix as its loading is less than 0.3 after rotation. Thus the total number of items is now reduced to 16. The roles of each of the factors are now analyzed. It is found that the factor F1 relates to Service Requirements, factor F2 relates to System Requirements, Factor F3 relates to Learner and Instructor Attitude whereas factor F4 relates to Learning Outcome of a web learning system. The set of factors along with the related items is shown in Table 6. 


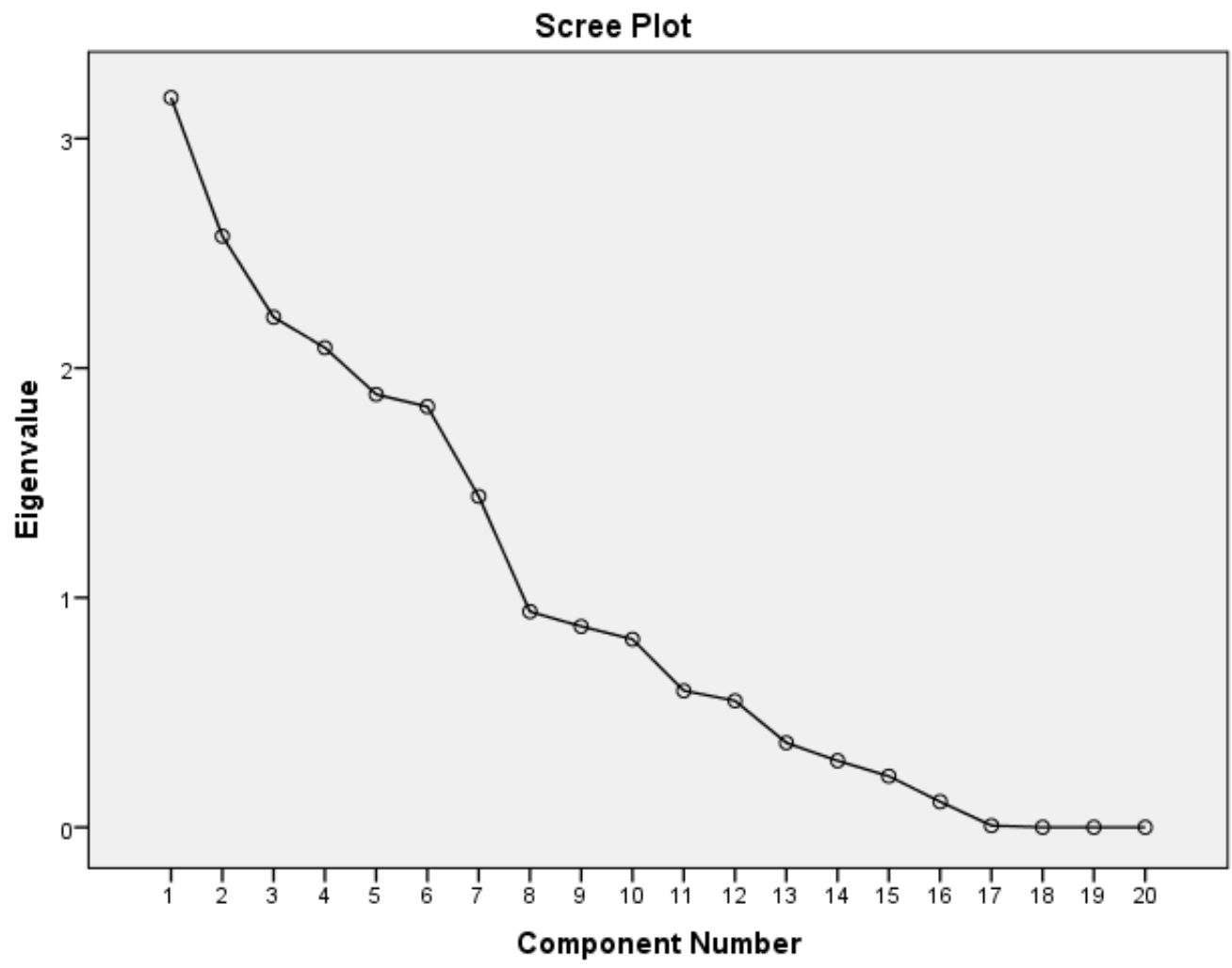

Fig. 2. Scree plot of the Eigen Values

\subsection{Reliability of the Factor Structure}

The purpose of the reliability test is to determine whether the same survey instrument with a different data set would generate the same factor structure. The test used by most researchers in this respect is Cronbach alpha [10]. Cronbach alpha generally increases with inter correlations among survey items and thus its value is maximized when all items measure the same latent construct. A value of alpha greater than 0.9 indicates excellent degree of internal consistency, a value of 0.7 to 0.9 indicates good deal of internal consistency, a value of 0.6 to 0.7 indicates acceptable degree of internal consistency whereas a value less than 0.6 indicates poor degree of internal consistency [23]. For the factors structure shown in Table 4 derived from survey data set, it is found that Cronbach alpha is 0.782 which indicates high level of internal consistency. The Cronbach alpha for each of the four factors were found to be 0.731 , $0.764,0.711$ and 0.694 which again indicates good deal of internal consistency within the factors. The item total statistics do not show any significant increase of Cronbach alpha if any of the factors are deleted and hence no further changes are made to the factor structure.

\subsection{Checking the Degree of Significance between the Factors}

Unpaired t-test [14] was applied on the average values between the items factor wise. The reason for applying unpaired t-test was the variable number of items for each factor. The degree of significance determined by two-tailed $p$ value is grouped into following categories: Statistically Very Significant (SVS), Statistically Extremely Significant (SES), Statistically Not Significant (SNS). The corresponding results are shown in Table 5 . 
Table 5. Degree of significance between factors derived from t-test

\begin{tabular}{|l|l|l|l|l|}
\hline & F1 & F2 & F3 & F4 \\
\hline F1 & X & $\begin{array}{l}0.0028 \\
\text { SVS }\end{array}$ & $\begin{array}{l}0.0003 \\
\text { SES }\end{array}$ & $\begin{array}{l}0.0005 \\
\text { SES }\end{array}$ \\
\hline F2 & $\mathrm{X}$ & $\mathrm{X}$ & $\begin{array}{l}0.0012 \\
\text { SVS }\end{array}$ & $\begin{array}{l}0.0012 \\
\text { SVS }\end{array}$ \\
\hline F3 & $\mathrm{X}$ & $\mathrm{X}$ & $\mathrm{X}$ & $\begin{array}{l}0.1874 \\
\text { NSS }\end{array}$ \\
\hline
\end{tabular}

It is observed that in most cases the degree of significance between the factors is either very or extremely significant except between F3 and F4. Thus it may be deduced that these factors are by and large independent of each other and may be assumed as a basis for evaluation of Web based learning systems.

\subsection{Estimating the Degree of Importance of each Factor}

Factor Scores [11] corresponding to each item loadings was used to compute the degree of importance corresponding to each item and factor. For this the Component Score Coefficient Matrix was used which was derived from linear regression model. Each item was assigned a score derived from this matrix. Each factor score corresponding to an item is divided by the sum of scores for the corresponding factor. This score in terms of percentage gives the degree of importance of each item. As an example, factor scores corresponding to $\mathrm{I}_{2}, \mathrm{I}_{13}$ and $\mathrm{I}_{17}$ are 0.152, 0.314 and 0.123 respectively. Thus the degree of importance for $\mathrm{I}_{2}$ in percentage is given as $(0.152 /(0.152+0.314+0.123) \mathrm{X} 100)$ $=25.80 \%$. Similarly the degree of importance for $\mathrm{I}_{13}$ and $\mathrm{I}_{17}$ are computed as $53.32 \%$ and $53.32 \%$ respectively. The degrees of importance corresponding to other items for each factor are computed similarly. After these computations, the degree of importance of each factor is computed. Similar methods are employed for computing these from their respective factor scores. The final model along with the items, factors and their relative degree of importance is enumerated in Table 6.

Table 6. Factor Structure with degree of importance

\begin{tabular}{|c|c|c|c|}
\hline $\begin{array}{l}\text { Factor } \\
\text { Reference }\end{array}$ & $\begin{array}{l}\text { Factor with } \\
\text { degree of } \\
\text { importance }\end{array}$ & $\begin{array}{l}\text { Item } \\
\text { Reference }\end{array}$ & Items with degree of importance \\
\hline \multirow[t]{4}{*}{ F1 } & \multirow{4}{*}{$\begin{array}{l}\text { Service } \\
\text { Requirements } \\
(25.13 \%)\end{array}$} & $\mathrm{I}_{3}$ & Knowledge Management (27.13\%) \\
\hline & & $\mathrm{I}_{9}$ & LO Reusability $(11.47 \%)$ \\
\hline & & $\mathrm{I}_{15}$ & Remedial Support (31.09\%) \\
\hline & & $\mathrm{I}_{19}$ & Collaborative Support (30.31\%) \\
\hline \multirow[t]{5}{*}{$\mathrm{F} 2$} & \multirow{5}{*}{$\begin{array}{l}\text { System } \\
\text { Requirements } \\
(17.21 \%)\end{array}$} & $\mathrm{I}_{4}$ & Security $(26.43 \%)$ \\
\hline & & $\mathrm{I}_{2}$ & Ease of Use $(15.14 \%)$ \\
\hline & & $\mathrm{I}_{10}$ & Reliability $(17.13 \%)$ \\
\hline & & $\mathrm{I}_{16}$ & Scalability $(23.18 \%)$ \\
\hline & & $\mathrm{I}_{18}$ & Maintainability (18.12\%) \\
\hline \multirow[t]{4}{*}{ F3 } & \multirow{4}{*}{$\begin{array}{l}\text { Learner and } \\
\text { Instructor } \\
\text { Attitude } \\
(27.17 \%)\end{array}$} & $\mathrm{I}_{1}$ & Instructor Knowledge (19.58 \%) \\
\hline & & $\mathrm{I}_{5}$ & Learner Computer Aptitude (23.14\%) \\
\hline & & $\mathrm{I}_{14}$ & Learner Communication skills $(27.02 \%)$ \\
\hline & & $\mathrm{I}_{20}$ & Instructor Friendliness $(30.26 \%)$ \\
\hline \multirow[t]{3}{*}{$\mathrm{F} 4$} & \multirow{3}{*}{$\begin{array}{l}\text { Learning } \\
\text { Outcome } \\
(30.31 \%)\end{array}$} & $\mathrm{I}_{2}$ & Learner Evaluation $(25.80 \%)$ \\
\hline & & $\mathrm{I}_{13}$ & Learner Employment $(53.32 \%)$ \\
\hline & & $\mathrm{I}_{17}$ & System Evaluation $(20.88 \%)$ \\
\hline
\end{tabular}




\section{Discussions}

The results derived in the previous section are analyzed here. It is found that the factor Service Requirement has moderately high degree $(25.13 \%)$ of importance. Within these the items Knowledge Management (27.13\%), Remedial Support (31.09\%) and Collaborative Support (30.31\%) have high degree of importance. Concept Maps has been used as a Knowledge Management tools in all the developed systems (DHP-CM, DHP-WCM, IDRLS, CLS). In IDRLS students were first given to study the course in a conventional manner. Exams were then conducted to evaluate these students. Based on these exam results, the Concept Map of learning was constructed. This Concept Map was then used as a learning sequence. Thus the learning systems developed are remedial in nature and hence this factor was given high degree of importance. Collaborative techniques have also been employed to construct the Concept Map of learning group wise (CLS). High degree of importance to this item indicates that students are satisfied with this collaborative learning scheme. Although Learning Objects were constructed for all the learning systems but they were not reused indicating a poor degree of importance (11.47\%).

The factor System Requirements has poor degree of importance (17.21\%). System designers and software engineers are mainly behind system construction and hence this factor has failed to ignite the interest among the learners. Within these the items Security $(26.43 \%)$ and Scalability $(23.18 \%)$ has attracted higher degree of attention. IDRLS and CLS have used login-id and password as security mechanism. The effect of scalability has been examined in details in CLS. It has been found that learner performance varies with change in group size. The items Ease of Use (15.14\%), Reliability (17.13\%) and Maintainability (18.12\%) attract poor degree of importance as they fail to appeal to the learners.

The factor Learner and Instructor Attitude $(27.17 \%)$ is given moderately high degree of importance. Learners who are not conversant with web based learning techniques would obviously like the instructor to be friendly $(30.26 \%)$ and hence its high degree of importance. Learner Communication skills $(27.02 \%)$ are also important as it enhances collaboration (CLS). It has also been found that certain learners are the first time users of computers or mobile devices for learning purpose. This is perhaps suggests moderate degree of importance of Learner Computer Aptitude $(23.14 \%)$. Finally most of the subject materials have been stored in the form of Learning Objects. The learners have mostly used these for learning and hence much importance has not been given to Instructor Knowledge (19.58 \%).

Finally as it turned out most important factor is Learning Outcome (30.31\%). Students are mostly interested in the Employment $(53.32 \%)$ opportunities they would get after completion of the course and hence very high degree of importance of this item. Since the systems developed were mainly used by students who had once performed poorly in the examinations, students were perhaps concerned with the methods of Evaluation $(25.80 \%)$ as well. Thus a moderately high degree of importance is given to this factor. Finally, group dynamics of the collaborative process were evaluated in System Evaluation $(20.88 \%)$. Poor degree of importance to this item suggests that users are not interested in evaluating collaboration dynamics.

\section{Comparative Study}

This section compares the results of the current study with similar pioneering research works done in this field. The assessment models compared with present study are E-learner satisfaction determination model developed by Wang [26], E-learning impact determination model proposed by Alkhalaf et al. [5] and the Educational Web Site Evaluator (EWSE) developed by Hwang et al. [17]. The aim of the first two studies is to develop a model for estimating E-learner's satisfaction similar to the present study. The third study develops a model for evaluating educational websites. It has been chosen for the purpose of comparison since its method 
of evaluation is similar to the present study. The parameters used for comparison of these studies are now presented:

(i) Basis of evaluation model: The entities involved in web based education include learners, instructors, system developers and many others. A multidimensional model based on sound theoretical and mathematical principles should be used in constructing the assessment model. Theoretical frameworks may thus be needed for developing measures and Statistical techniques for assessing dimensionality [27].

(ii) Proposed evaluation model: The proposed model may contain multiple dimensions with several items in each dimension.

(iii) Entities involved in evaluation: In most cases survey instruments have been used as a basis of developing the evaluation model. The participants of the survey include the learners who have had some experience in using web based learning systems.

(iv) Software used for simulation: The output of the survey instrument is fed into software for dimension reduction and reliability estimation.

(v) Limitations of the model: The efficacy of the developed evaluation model is greatly dependent on the quality of the learners on whom the survey instrument is applied and the statistical techniques used in deriving the model.

The comparative study of the papers listed above with the current study on the above proposed parameters is presented in Table 7.

Table 7. Comparison of current study with related works

\begin{tabular}{|c|c|c|c|c|}
\hline Parameters & Wang [26] & Alkhalaf et al. [5] & Hwang et al. [17]. & Present Study \\
\hline Theoretical Framework & $\begin{array}{l}\text { Hypothesis defining } \\
\text { the relation between } \\
\text { learner satisfaction and } \\
\text { intension }\end{array}$ & $\begin{array}{l}\text { Information System } \\
\text { Impact measurement } \\
\text { model }\end{array}$ & $\begin{array}{ll}\text { Evaluation } & \text { criteria } \\
\text { derived from domain } \\
\text { experts }\end{array}$ & $\begin{array}{l}\text { Evaluation } \\
\text { criteria proposed } \\
\text { by the authors }\end{array}$ \\
\hline $\begin{array}{l}\text { Statistical techniques } \\
\text { used }\end{array}$ & $\begin{array}{lr}\begin{array}{l}\text { Exploratory } \\
\text { Analysis, }\end{array} & \text { Factor } \\
\text { reliability test } & \end{array}$ & $\begin{array}{ll}\text { Chi square goodness } \\
\text { test }\end{array}$ & $\begin{array}{l}\text { Multiple criteria } \\
\text { decision making, Fuzzy } \\
\text { theory, Analytic } \\
\text { Hierarchy Process }\end{array}$ & $\begin{array}{l}\text { Factor Analysis, } \\
\text { Cronbach alpha, } \\
\text { t-test, } \\
\text { Regression } \\
\text { analysis }\end{array}$ \\
\hline Proposed Dimensions & $\begin{array}{l}\text { Learner interface, } \\
\text { learning community, } \\
\text { Content, } \\
\text { Personalization }\end{array}$ & $\begin{array}{lr}\text { System } & \text { and } \\
\text { information } & \text { quality, } \\
\text { Individual and } & \text { and } \\
\text { organizational impact }\end{array}$ & $\begin{array}{l}\text { Design of student } \\
\text { interface, quality of } \\
\text { instructional contents, } \\
\text { organizational impact }\end{array}$ & $\begin{array}{l}\text { Service and } \\
\text { system } \\
\text { requirements, } \\
\text { learner and } \\
\text { instructor } \\
\text { attitude, learning } \\
\text { outcome }\end{array}$ \\
\hline Survey Entities & $\begin{array}{lr}116 & \text { e-learners } \\
\text { answered } 26 & \text { questions } \\
\text { on } & \text { e-learning } \\
\text { satisfaction } & \end{array}$ & $\begin{array}{l}528 \quad \text { participants } \\
\text { answered } 37 \text { questions } \\
\text { on e-learning impact }\end{array}$ & $\begin{array}{l}\text { Undergraduate students } \\
\text { evaluated educational } \\
\text { web sites }\end{array}$ & $\begin{array}{l}97 \text { learners rated } \\
20 \text { items on their } \\
\text { perceived } \\
\text { degree } \\
\text { importance }\end{array}$ \\
\hline $\begin{array}{l}\text { Simulation Software } \\
\text { used }\end{array}$ & Not Reported & SPSS & $\begin{array}{l}\text { Unified Modeling } \\
\text { Language (UML) }\end{array}$ & SPSS \\
\hline Limitations & $\begin{array}{l}\text { Sample collected from } \\
\text { Taiwan only; } \\
\text { Nomological validity } \\
\text { check not stringent }\end{array}$ & $\begin{array}{l}\text { Reliability of the model } \\
\text { not tested }\end{array}$ & Not Reported & $\begin{array}{l}\text { system } \\
\text { developed on } \\
\text { the basis of the } \\
\text { systems } \\
\text { developed by } \\
\text { the authors }\end{array}$ \\
\hline
\end{tabular}

\section{Conclusion}

The current work proposes a set of 20 items used for evaluating the web learning systems developed by the authors $[2,3,4]$. These items are ranked by a set of 140 learners who used these systems by a survey. Factor Analysis is then applied on this survey data to develop a multi-dimensional model for assessing web based learning systems. It has been found that the most important dimension is 
Learning Outcome which is consistent with the general observations about any learning system. Within this dimension it is found that most important item is Learner Employment which again is consistent with general observations. It is to be noted that this factorization is based solely on student observations; the feedback of instructors, system developers, administrators have not been taken into account. However the comparative study with similar research papers indicate that proposed research methodology and results obtained is comparable with these.

In spite of this there are certain areas where the authors intend to work on. The relationships between the various items within the factors have not been explored. As an example, there could be interdependence between the items Remedial Support ( $\left.\mathrm{I}_{15}\right)$ and Learner Evaluation $\left(\mathrm{I}_{2}\right)$. This is due to the fact evaluation is done after performing remedial learning in the developed systems. There could be a similar interdependence between the items Collaborative Support ( $\left.\mathrm{I}_{19}\right)$ and Communication Skills $\left(\mathrm{I}_{14}\right)$. Future studies may involve checking these interdependencies. Finally it may be stressed that the Assessment Model developed in this paper is not general in nature, since it has been derived on the basis of the systems developed by the authors. Future studies could develop an assessment model which is more general in nature. Another extension of this work would be to develop a set of quality metrics and computation of these metrics for the items derived in the factor structure for the proposed Web based Learning Systems.

\section{References}

[1] Abdi, H. "Factor Rotations in Factor Analyses," Encyclopedia of Social Sciences Research Methods, 2003.

[2] Acharya A, Sinha D. "A Concept Map Approach to Supporting Diagnostic and Remedial Learning Activities," Advanced Computing, Networking and Informatics, Kolkata, 24-27th June, 2014, 565-57, Springer India .

[3] Acharya A, Sinha D "Construction of
Automated Concept Map of Learning using Hashing Technique," Frontiers in Intelligent Computing Theory and Applications, Bhubneshwar, 14-15th November,2015, 567- 578, Springer India.

[4] Acharya A, Sinha D "A Weighted Concept Map Approach to Generate Learning Guidance in Science Courses," Information Systems Design and Intelligent Applications, Kalyani, 8-9th January, 2015, 143- 152, Springer, India.

[5] Alkhalaf, S, Drew, S, Alhussain, T. "Assessing the impact of e-learning systems on learners: a survey study in the KSA," Social and Behavioral Sciences(47), 2012, $98-104$.

[6] Argyrous, G, Statistics for Research: With a Guide to SPSS, Sage South Asia, 2012.

[7] Bruffee, K: Collaborative Learning. The Johns Hopkins University Press. Baltimore, 1993, 28-51.

[8] Cherian E. J, Williams P, "Mobile Learning: The Beginning of the End of Classroom Learning," WCECS ,2008.

[9] Costello A. B., Osborne J. W., "Best Practices in Exploratory Factor Analysis: Four Recommendations for Getting the Most From Your Analysis," Practical Assessment Research \& Evaluation, (10:7), 2005.

[10] Cronbach L J. "Coefficient alpha and the internal structure of tests", Psychometrika (16:3),1953, 297-334.

[11] DiStefano, C., Zhu, M. Mîndrilă, D., "Understanding and Using Factor Scores: Considerations for the Applied Researcher", Practical Assesment, Research \& Evaluation, (14 :20), 2009.

[12] Dillenbourg, P. Collaborative Learning: Cognitive and Computational Approaches. Advances in Learning and Instruction Series. Elsevier Science, New York, 1999.

[13] Gafni R, "Framework for Quality Metrics in Mobile-Wireless Information Systems", Interdisciplinary Journal of Information, Knowledge, and Management, (3), 2008. 
[14] Goon A. M., Gupta M. K., Dasgupta B., Fundamentals of Statistics, Vol 1, World Press, Kolkata, India, 1975.

[15] Hutcheson G. D., Sofroniou N, The Multivariate Social Scientist: Introductory Statistics Using Generalized Linear Models, Sage Publications, 1999.

[16] Haan J, Kamber M, Data Mining: Concepts and Techniques, Third Edition, Elsevier, 2011.

[17] Hwang G. J, Huang T K, Tseng J C R, "A group-decision approach for evaluating educational web sites," Computers \& Education(42), 2004, 6586.

[18] Hwang G, “A computer assisted approach to diagnosing student learning problems in science courses", Journal of Information Science and Engineering, 2003, pg 229-248.

[19] MacCallum R. C., Widaman K. F., Preacher K. J., Hong S, "Sample Size in Factor Analysis: The Role of Model Error," Multivariate Behavioral Research(36:4), 2001, 611-637.

[20] Mela C. F., Kopalle P. K., "The impact of collinearity on regression analysis: the asymmetric effect of negative and positive correlations," Applied Economics(34), 2002, 667-677.
[21] Motiwalla L, "Mobile learning: A framework and evaluation," Computers \& Education(49), 2007, 581-596.

[22] Novak Joseph D and Canas Alberto J, "Theoretical Origins of Concept Map, How to construct them and their used in Education," Reflecting Education(3:1),200729-42.

[23] Nunnally J. C. Psychometric Theory, McGraw-Hill, New York, 1978.

[24] Parsons D, Ryu H, Cranshaw M, "A Design Requirements Framework for Mobile Learning Environments," Journal of Computers(2:4), 2007.

[25] Pocatilu P. "Developing Mobile Learning Applications for Android using Web Services," Informatica Economică(13:3), 2009.

[26] Wang Y, "Assessment of learner satisfaction with asynchronous electronic learning systems," Information \& Management(41), 2003, 75-86.

[27] Wang Y, Shee D, "Multi-criteria evaluation of the web-based e-learning system: A methodology based on learner satisfaction and its applications," Computers \& Education 50, pp. 894-905, 2008.

[28] Park J.S, Chen M.S, Philip S Y, "An effective Hash based Algorithm for mining Association Rules",1998.

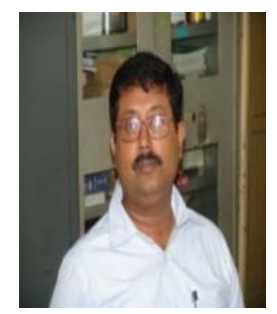

Anal ACHARYA is Assistant Professor in the Department of Computer Science in St Xavier's College, Kolkata. He was the Head of the Department of Computer Science from the period of 01.01.2009 to 30.06.2013. His present research interests include Data Mining and Intelligent Learning Systems. He has above 15 years of experience in undergraduate and post graduate teaching \& supervised several post graduate dissertations. He has several accepted papers in International Conferences and Journals.

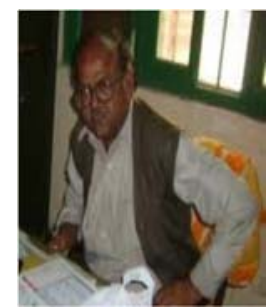

Devadatta SINHA is currently Professor in Computer Science and Engineering Department in University of Calcutta, Kolkata. He was the Head of the department on several occasions. His research interests include Distributed Systems. He has over 30 years of experience and has supervised several PhD students. 


\section{Appendix A: Survey Instrument}

\section{PART I (Back ground Information)}

1. Name:

2. Course of study:

3. Age:

4. Years of computer usage:

5. College Name:

6. Learning system used (Tick at least one):

CM-DHP

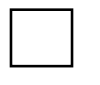

WCM-DHP
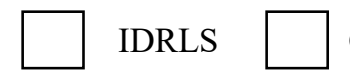

CLS

PART II (Item Rating Information)

7. Rank each of these items (1-20) based on your perceived degree of importance.

\begin{tabular}{|l|l|l|}
\hline $\begin{array}{l}\text { Item } \\
\text { Reference }\end{array}$ & Item Name & Rating \\
\hline $\mathrm{I}_{1}$ & Instructor Subject Knowledge & \\
\hline $\mathrm{I}_{2}$ & Learner Evaluation & \\
\hline $\mathrm{I}_{3}$ & Knowledge Management & \\
\hline $\mathrm{I}_{4}$ & Security & \\
\hline $\mathrm{I}_{5}$ & Learner's Computer Aptitude & \\
\hline $\mathrm{I}_{6}$ & Interactivity & \\
\hline $\mathrm{I}_{7}$ & Ease of use & \\
\hline $\mathrm{I}_{8}$ & Timeliness & \\
\hline $\mathrm{I}_{9}$ & Learning Object(LO) reusability & \\
\hline $\mathrm{I}_{10}$ & Reliability & \\
\hline $\mathrm{I}_{11}$ & Instructor's availability & \\
\hline $\mathrm{I}_{12}$ & Learner satisfaction & \\
\hline $\mathrm{I}_{13}$ & Employment & \\
\hline $\mathrm{I}_{14}$ & Learner's communication skills & \\
\hline $\mathrm{I}_{15}$ & Remedial learning support & \\
\hline $\mathrm{I}_{16}$ & Scalability & \\
\hline $\mathrm{I}_{17}$ & System Evaluation & \\
\hline $\mathrm{I}_{18}$ & Maintainability & \\
\hline $\mathrm{I}_{19}$ & Collaborative Support & \\
\hline $\mathrm{I}_{20}$ & Instructor friendliness & \\
\hline
\end{tabular}

\section{PART III (Learning Experience Description)}

8. Briefly describe your experience of using web based learning:

9. Suggestions: 